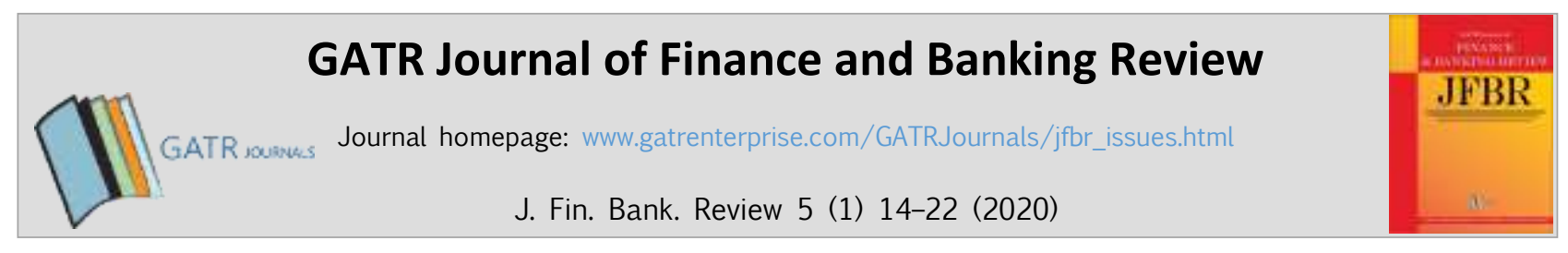

\title{
Anomalies of Banking Intermediation and Profit Growth (Study on the 10 Largest Banks in Indonesia)
}

\author{
Herry Achmad Buchory
}

Sekolah Tinggi Ilmu Ekonomi Ekuitas, Jln. PHH. Mustopa No. 31, 40124, Bandung, Indonesia

\begin{abstract}
Objective - One of the bank's main goals is to obtain profit mainly from the intermediation process. The implementation of the Indonesian banking intermediary function in the year 2017 is not optimal, as indicated by credit growth in the year 2017 which only reached 8,35\%. This phenomenon also occurs in the 10 largest banks in Indonesia. In 2017 the intermediation function has decreased but profits have increased. The aim of this study is to analyze the influence of banking intermediation on profit growth and whether credit quality and operational efficiency affect profit growth. An indicator of banking intermediation is a loan to deposits ratio (LDR), credit quality with non-performing loans (NPLs), the operating efficiency with the ratio of operating expense to operating income (OEOI) and profit growth is measured by the amount of profit.

Methodology - Descriptive and verification methods will be used in this study, with data from the 10 largest banks financial statements in Indonesia for the period 2016-2017 while data analysis uses multiple linear regression.

Findings - The findings of this study show that partially LDR has a positive effect although the effect is not significant on Profit; NPLs have a negative effect on Profit and the effect is significant; OEOI has a negative effect even though the effect is not significant on Profit; Simultaneously, the variable LDR, NPLs, OEOI have a significant effect on profit.

Novelty - Compared to previous studies, bank profit growth is not only influenced by banking intermediation, but if banks can maintain credit quality and improve operational efficiency, bank profits will grow

Type of Paper: Empirical

Keywords: loan to deposit ratio, non-performing loans, the ratio of operating expenses to operating income, profit growth.

Reference to this paper should be made as follows: Buchory; H.A. (2020). Anomalies of Banking Intermediation and Profit Growth (Study on the 10 Largest Banks in Indonesia), J. Fin. Bank. Review, 5 (1): pp. $14-22$ https://doi.org/10.35609/jfbr.2020.5.1(2)
\end{abstract}

JEL Classification: G21, G32.

\section{Introduction}

One of the objectives of the establishment of a company is to obtain profits in order to increase shareholder wealth. Likewise for banking companies.

\footnotetext{
* Paper Info: Revised: February 13, 2020

Accepted: June 30, 2020

* Corresponding author: Herry Achmad Buchory

E-mail: achmad.buchory@gmail.com

Affiliation: Sekolah Tinggi Ilmu Ekonomi Ekuitas, Jln. PHH. Mustopa No. 31, 40124, Bandung, Indonesia
} 
Revenues earned commercial banks in Indonesia are mostly sourced from the implementation intermediation, mainly of loans or credit. Over the past 3 years, sources of bank income were obtained from loan interest income, namely $69.75 \%$ (2015); $69.66 \%$ (2016) and $67.56 \%$ (2017). This data shows that the implementation of the banking intermediary function plays an important role in generating bank revenue and increasing profit growth. Therefore, if the banking intermediary function increases, bank profits will also increase, and vice versa.

Implementation of intermediary function by Indonesian Banking in 2017 did not maximize, as can be seen from credit growth of only $8.35 \%$. This case was also experienced by the 10 largest banks with a market share of banking in Indonesia amounted to $62.82 \%$. Banking intermediation indicated by Loan to Deposit Ratio (LDR) reached by the 10 largest banks in Indonesia in 2017 was $91.20 \%$ which decreased to $90.45 \%$. But the profits obtained in 2017 grew by 22, 11\% compared to 2016. (Financial Service Authority of Republic Indonesia, Indonesia Banking Statistics, 2017). Thus there are anomalies between banking intermediation and profit growth. It is possible that the profit growth obtained by the 10 largest banks in Indonesia is not only sourced from the implementation of the intermediation function but is influenced by other factors such as better asset quality or increased levels of operational efficiency.

The aim of this study is to know the effect of banking intermediation on profit growth and whether credit quality and operational efficiency affect on profit growth.

The results of this study will provide contributions and benefits for the commercial bank managers in managing liability assets to increase profit growth

\section{Literature Review}

Profit is the difference between actual incomes from transactions of a certain period is reduced by expenses incurred to earn such income. Profit is a summary of the net results of business operating activities in a certain period stated in financial terms (Subramanyam, 2009) Meanwhile, according to (Harahap, 2015) the profit is the difference between actual income derived from certain corporate transactions during the period reduced by the costs incurred to earn that income.

Profit is the most preferred enterprise information in the financial markets. Determine and explain the profit of a business in one period is the main purpose of the income statement. The role of profits is to provide both a measurement of changes in shareholder wealth over the period, and to estimate current operating income, to the extent that the company can cover operating costs and generate returns to its shareholders and specifically the second role, as an indicator of company profitability (Subramanyam, 2009).

Hence the importance of the role of profit in a company, including banks, then firms will strive to achieve profit growth every year. The profit growth is calculated by deducting profit this year with last year's profit divided by last year's profit. Good company profit growth reflects that the company's performance is also good. Therefore profit growth is a measure of the performance of a company, the higher the profit achieved by the company, indicating the better the company's performance (Wibisono \& Triyonowati, 2016).

Profits growth is influenced by several factors including: (1). The size of the company, (2). Age of the company, (3). Leverage Level, (4). The level of sales, and (5). Change in past profit (Gunawan \& Wahyuni, 2014) .

Each bank aims to make a profit. With the profit, the bank can maintain business continuity and increase shareholder wealth. Profit is also one of the considerations for investors who will invest their money in banking stocks. Because the role of profit is important for the bank, the bank will always increase profit growth. The profit is obtained by the bank from the banking intermediation process. Intermediation process is the process of collecting and distributing funds by banks. In other word, intermediation process in banking is the process of collecting public funds and channeling them back to the public, especially in the form of credit. Bank act as intermediaries in the allocation of financial resources. The basic business of banking is funding loans with deposits (Koch, 2014). Therefore, one measure of the optimization of the implementation of bank intermediation is to use loans to deposits ratio (LDR). 
Research by (Samad, 2015) states that bank-specific factors such as loan-deposit ratio are significant factors on profits. Then according to research conducted by (Buchory, 2016) that the financial intermediation function has an effect on bank profitability. Likewise according to (Egbe \& Collins, 2014) found that loans to total deposit ratio to be the determinant of profit in only in cooperative development bank in Nigeria. Meanwhile, according to research results, (Islam \& Rana, 2017) stated that a higher loan to deposit (LD) ratio contributed towards profitability, but not significantly in the private commercial banks of Bangladesh. Likewise according to (Menicucci \& Paolucci, 2016) found that banks with higher deposits and loans ratio tend to be more profitable but the effects on profitability are statistically insignificant in the European banking sector. And the findings of (Yigermal, 2017) stated that loan to deposit ratio has a negative and significant impact on banks ROA in the case of selected Ethiopian Private Banks. From the results of the above research, it was concluded that bank intermediation had an effect on profit. If banking intermediation increases, bank profits will grow.

However, if bank intermediation is not optimal, but the bank's profits experience growth, there are other factors that might affect profit growth, such as credit quality or credit risk and operating efficiency.

Credit risk is the potential variation in net income and market value of equity resulting from this nonpayment or delayed payment (Koch, 2014). Credit risk is the risk when borrowing customers fail to make some or all of their promised payment (Rose \& Hudgins, 2013). Meanwhile according to (Ghosh, 2012), credit risk as the potential that a borrower or counterparty will fail to meet its obligation in accordance with the agreed terms. Credit risk is one of the risks faced by banks, besides market risk, operational risk, operating environment risk, reputation risk, legal risk, money laundering risk, technology risk and control risk. According to Indonesian bank regulations and the Indonesian financial services authority, the risks faced by banks are credit risk, market risk, liquidity risk, operational risk, compliance risk, legal risk, reputation risk and strategic risk (Financial Service Authority of Republic Indonesia Regulation No.18/POJK.13/2016 about Implementation of Risk Management for Commercial Banking, 2016; Indonesian Bank Regulation No. 11/25/PBI/2009 about Implementation of Risk Management for Commercial Banking, 2009). In this study the indicators used to measure credit quality or credit risk are non-performing loans (NPLs)

According to the results of research (Erdogan \& Aksoy, 2016) found that the increase in non-performing loans among total loans, it was observed that profitability is inclined to decrease commercial banks' profits in Turkey. Furthermore, the research result (Islam \& Rana, 2017) found that non-performing loan (NPL) has a significant effect on the profitability of the selected private commercial banks in Bangladesh. Likewise according to (El-Kassem, 2017) found that non-performing loan (NPL) has a significantly and negatively affect ROAA of banks in Qatar; (Sinha \& Sharma, 2016) that credit risk has a negatively impacts the bank profitability in Commercial Bank in India; And (Petria, Capraru, \& Ihnatov, 2015) found that credit risk has influence on bank profitability both on ROAA and ROAE in EU 27 banking systems; Whereas (Buchory, 2016) research found that non-performing loans (NPLs) have positive and significant effect on ROA in Indonesian Regional Development Bank.

The profit growth of the 10 largest banks in Indonesia in 2017 may also be affected by the high level of operating efficiency. This is in line with previous studies, for example, research conducted by (Sinha \& Sharma, 2016) which found that operating efficiency has been found to be significantly and positively affecting the bank profit. Furthermore, the results of study (Buchory, 2016) state that operating efficiency measured by operating expenses to operating income (OEOI) has a negative and significant effect on ROA. Research result of (Ramadan, Kilani, \& Kaddumi, 2011) stated that high Jordanian bank profitability tends to be associated with the efficiency of cost management. Likewise according to (Le Thanh, Trang, \& Le Nhat, 2017) stated that management expense also has a negative relationship with the profitability of banks in the commercial banks listed on Vietnam's Stock Exchange. Then, according to (Islam \& Rana, 2017), operating expenses have a significant effect on the profitability of the selected private commercial banks in Bangladesh. And according to (El-Kassem, 2017) stated that cost to income ratio negatively and significantly impacts the performance of banks in Qatar measured by ROAA. 
Based on the research objectives and literature review, the research hypothesis can be formulated:

- The first hypothesis: LDR has a significant positive effect on profit

- The second hypothesis: NPLs have a significant negative effect on profit

- The third hypothesis: OEOI has a significant negative effect on profit

- The fourth hypothesis: LDR, NPLs, and OEOI have an effect on Profit

\section{Research Methodology}

In this study the authors chose a sample of the 10 largest banks from a population of 115 banks in Indonesia at the end of December 2017. This was done with the consideration that the 10 largest banks controlled the market share of banking assets in Indonesia amounting to $62.82 \%$. Thus the behavior of the 10 biggest banks will become a reference for other banks. Descriptive with verificative are two methods that will be used in this research. The financial statements for the 2016-2017 period of the 10 largest banks in Indonesia and the Indonesian Banking Statistics is a secondary data source used in this study.

While the data analysis techniques using multiple regression and hypothesis testing by the t-test and F-test statistic. Following are the regression equations:

$\mathrm{Y}=\mathrm{a}+\beta \mathrm{X}_{1}+\beta \mathrm{X}_{2}+\beta \mathrm{X}_{3}+\mathrm{e}$

Where, $\mathrm{Y}=\mathrm{Ln}$ Profit; $\mathrm{a}=\mathrm{A}$ constant which is the value of the variable $\mathrm{Y}$ when the variable $\mathrm{X}$ is 0 (zero); $\beta$ $=$ Coefficient of the regression line; $\mathrm{X}_{1}=\mathrm{LDR} ; \mathrm{X}_{2}=\mathrm{NPLs} ; \mathrm{X}_{3}=\mathrm{OEOI}$; and, $\mathrm{e}=$ Residual.

\section{Results}

From secondary data collected, then processed and obtained results as presented in table 4.1 below:

Table 4.1. The Development of the LDR, NPLs, OEOI and PROFIT GROWTH of The 10 largest banks in Indonesia in 2016 - 2017

\begin{tabular}{|l|l|l|l|l|l|l|}
\hline $\begin{array}{l}\text { BANK } \\
\text { NAME }\end{array}$ & YEARS & $\begin{array}{l}\text { LDR } \\
(\boldsymbol{\%})\end{array}$ & $\begin{array}{l}\text { NPLs } \\
(\boldsymbol{\%})\end{array}$ & $\begin{array}{l}\text { OEOI } \\
(\boldsymbol{\%})\end{array}$ & $\begin{array}{l}\text { PROFIT } \\
(\text { IDR-BN) }\end{array}$ & $\begin{array}{l}\text { PROFIT } \\
\text { GROWTH (\%) }\end{array}$ \\
\hline BRI & IV/2016 & 87.77 & 2.03 & 68.69 & 25.753 & \\
\hline & $\mathrm{IV} / 2017$ & 87.77 & 2.10 & 94.44 & 28.469 & 10.55 \\
\hline BNI & $\mathrm{IV} / 2016$ & 90.41 & 2.96 & 73.59 & 10.776 & \\
\hline & $\mathrm{IV} / 2017$ & 85.58 & 2.26 & 70.99 & 13.045 & 21.06 \\
\hline Mandiri & $\mathrm{IV} / 2016$ & 85.86 & 1.38 & 80.94 & 13.071 & \\
\hline & $\mathrm{IV} / 2017$ & 88.11 & 1.06 & 71.78 & 20.010 & 53.09 \\
\hline BTN & IV/2016 & 102.66 & 1.85 & 84.48 & 2.619 & \\
\hline & $\mathrm{IV} / 2017$ & 103.13 & 1.66 & 82.06 & 3.027 & 15.58 \\
\hline BCA & $\mathrm{IV} / 2016$ & 77.10 & 1.30 & 60.40 & 19.753 & \\
\hline & $\mathrm{IV} / 2017$ & 78.20 & 1.50 & 58.60 & 22.164 & 12.21 \\
\hline Danamon & $\mathrm{IV} / 2016$ & 100.18 & 3.47 & 77.25 & 2.669 & \\
\hline & $\mathrm{IV} / 2017$ & 94.79 & 2.92 & 72.11 & 3.682 & 37.95 \\
\hline CIMB Niaga & $\mathrm{IV} / 2016$ & 95.37 & 3.93 & 88.73 & 1.268 & \\
\hline & $\mathrm{IV} / 2017$ & 94.67 & 3.78 & 88.27 & 2.140 & 68.77 \\
\hline Maybank & $\mathrm{IV} / 2016$ & 88.02 & 4.17 & 87.52 & 1.181 & \\
\hline & $\mathrm{IV} / 2017$ & 87.63 & 4.15 & 85.43 & 1.080 & -8.55 \\
\hline OCBC-NISP & $\mathrm{IV} / 2016$ & 89.86 & 1.88 & 79.84 & 1.790 & \\
\hline & $\mathrm{IV} / 2017$ & 93.42 & 1.79 & 77.07 & 2.176 & 22.00 \\
\hline
\end{tabular}




\begin{tabular}{|l|l|l|l|l|l|l|}
\hline Panin & IV/2016 & 93.20 & 0.94 & 83.61 & 1.571 & \\
\hline & IV/2017 & 91.20 & 0.74 & 79.25 & 2.002 & 27.43 \\
\hline $\begin{array}{l}\text { Average 2016 } \\
\text { Average 2017 }\end{array}$ & 91.04 & 2.39 & 78.51 & 8.05 & \\
\cline { 2 - 7 } & 90.45 & 2.20 & 78.00 & 9.78 & 21.56 \\
\hline
\end{tabular}

Source: Published Financial Statements, period 2016 - 2017, processed.

From secondary data collected, then processed and obtained results as presented in table 4.2 below:

Table 4.2. Results of Statistical Data

\begin{tabular}{|l|l|l|l|l|}
\hline Description & & LDR & NPLS & OEOI \\
\hline Regression Coefficients & 4.641 (Constant) & -.029 & -.121 & -.014 \\
\hline R & .692 & & & \\
\hline R-Square & .478 & & & \\
\hline T-test & 3.734 & -1.796 & -1.328 & -1.102 \\
\hline Sig. & .002 & .091 & .023 & .287 \\
\hline F-test & 4.893 & & & \\
\hline Sig. & .013 & & & \\
\hline
\end{tabular}

Source: Output SPSS Ver. 23.0

\section{Discussion}

LDR, NPLs, OEOI, and Profit Growth period 2016-2017 were achieved by 10 largest banks in Indonesia, as can be seen in Table 4.1 above may explain:

The LDR achieved in 2017 is an average of $90.45 \%$, a decrease from 2016 of $91.06 \%$, although it is higher than the national banking LDR of 78.40\%. LDR of the 10 largest banks in 2017, five banks declined (BNI, Danamon, CIMB-Niaga, Maybank, and Panin), four banks increased (Mandiri, BTN, BCA, and OCBCNISP) and one bank remained (BRI). The highest LDR in 2017 was reached by BTN (103.13\%) and the lowest LDR was achieved by BCA (78.20\%).

The average value of NPLs achieved in 2017 is $2.20 \%$, a decrease from 2016 of $2.39 \%$, lower than the national banking NPLs of 2.89\%. NPLs of the 10 largest banks in 2017, eight banks declined (BNI, Mandiri, BTN, Danamon, OCBC-NISP, CIMB-Niaga, May-bank and Panin), two banks increased (BRI and BCA). The highest NPLs in 2017 was achieved by CIMB-Niaga (3.78\%) and the lowest NPLs was achieved by Panin (0.74\%).

The average value of OEOI achieved in 2017 is $78.00 \%$, a decrease from 2016 of $78.51 \%$, lower than the national banking OEOI of 78.64\%. OEOI of the 10 largest banks in 2017, nine banks declined (BNI, Mandiri, BTN, BCA, Danamon, OCBC-NISP, CIMB-Niaga, May-bank and Panin), one bank increased (BRI). The highest OEOI in 2017 was achieved by BRI (94.44\%) and the lowest OEOI was achieved by BCA (58.6\%).

And the profit achieved in 2017 was IDR 99.603 billion, growing by $20.94 \%$ compared to 2016 profit of IDR 82.360 billion. Of the 10 largest banks, 9 banks profit growth and one bank (Maybank) has decreased by $14.79 \%$. The highest profit growth was achieved by Mandiri $(50.39 \%)$. The profit contribution of the 10 largest banks in Indonesia to the profits of national banks is $75.94 \%$.

From the 10 banks sampled in this study, the biggest profit growth in 2017 was achieved by CIMB Niaga (68.77\%), even though its LDR growth decreased from $95.37 \%$ to $94.67 \%$. However, CIMB Niaga can improve the quality of its credit as seen from the reduction in NPL by negative (-) $0.15 \%$. Besides that, CIMB Niaga can also improve efficiency as can be seen from the decrease in the OEOI ratio of $0.46 \%$. Thus proving that although the banking intermediation function performed by CIMB Niaga in 2017 has decreased, but due to efforts made by CIMB Niaga by increasing income other than credit, improving credit quality and increasing operational efficiency, CIMB Niaga can achieve growth high profit. The same thing was achieved by Bank BNI, Danamon, and Panin. These banks, although their banking intermediary function has 
decreased, profits have grown. Profit growth can be achieved because these banks may make efforts to increase income other than credit such as fee-based income, improve credit quality (decreasing NPL indicators and increasing efficiency (as indicated by decreasing OEOI ratio).

Whereas at Bank Mandiri, profit growth achieved in 2017 was 53.09\%, whereas Bank Mandiri's LDR growth was only $2.25 \%$ but Bank Mandiri was also able to improve its credit quality as seen from the NPL reduction of negative (-) $0.32 \%$. In addition, Bank Mandiri can also improve efficiency as can be seen from the decline in the OEOI ratio of $9.16 \%$. It proves that although the banking intermediation function performed by Bank Mandiri in 2017 is less than optimal, but because there are efforts made by Bank Mandiri by increasing income other than credit, improving credit quality and increasing operational efficiency, Bank Mandiri can achieve high profit growth. The same thing was achieved by BRI, BTN, and OCBC-NISP.

Specifically in the case of Maybank banks, although intermediation achieved growth, credit quality has improved and efficiency has increased, but earnings have achieved negative growth or decreased. Maybank might make income from credit business the main source of bank income. So that when intermediation is not optimal, profit growth decreases. And also the limited sources of income from fee-based income

Based on the description above, it can be concluded that even though the LDR has decreased but the NPLs and OEOI have also declined, profit has grown.

From the results of processing statistical data as can be seen in Table 4.2, the equation can be made as follows:

LnPROFIT $=4.641-.029 \mathrm{LDR}-.121 \mathrm{NPLs}-.014 \mathrm{OEOI}$

Then the equation can be explained:

With a positive constant of 4.641 then if the LDR, NPLs, OEOI have a value of 0 , the profit increases by 4.641. The coefficient of regression for the LDR variable is -.029 , indicating an opposite relationship if the LDR increases by one unit, and the other variables are assumed to be fixed, then the Profit decreases by .029 and vice versa. The regression coefficients for NPL are -0.121 and OEOI are -0.014 indicating the opposite relationship, meaning that if the NPL and OEOI increase by one unit, the other variables are assumed to be fixed then the profit decreases 0.121 and 0.014 .

The correlation (R) LDR, NPLs, OEOI, and Profit, is .692, show a strong relationship (Sugiyono, 2013). While the determination (R-Square) is $0.478(47.8 \%)$, meaning Profit was influenced by LDR, NPLs, and OEOI of $47.8 \%$. and the remaining $52.2 \%$ influenced by other variables.

The results of the t-test value between LDR on Profit is 1.796 with a value of significant .091 is higher 0.05. This means that the LDR has a positive effect on profit even though it is not significant. Therefore the first hypothesis: LDR has a significant positive effect on Profit, accepted. The findings of this study support previous research by (Islam \& Rana, 2017) stated that a higher loan to deposit (LD) ratio contributed towards profitability, but not significantly in the private commercial banks of Bangladesh. Likewise according to (Menicucci \& Paolucci, 2016) found that banks with higher deposits and loans ratio tend to be more profitable but the effects on profitability are statistically insignificant in the European banking sector. Meanwhile, research by (Samad, 2015) states that bank-specific factors such as loan ratio are significant factors on profits. Then according to research conducted by (Buchory, 2016) that the financial intermediation function has an effect on bank profitability. Likewise according to (Egbe \& Collins, 2014) found that loans to total deposit ratio to be the determinant of profit in only in cooperative development bank in Nigeria. However, contrary to the results of (Yigermal, 2017) stated that loan to deposit ratio has a negative and significant impact on banks ROA in the case of selected Ethiopian Private Banks.

The results of the t-test value between NPLs on Profit is -1.328 with a value of significant .023 is lower 0.05. This means that NPLs have a significant negative effect on profit. Therefore the second hypothesis: 
NPLs have a significant negative effect on profit, accepted. The findings of this study support previous research by (Islam \& Rana, 2017) found that non-performing loan has a significant effect on the profitability of the selected private commercial banks in Bangladesh. Furthermore, according to (El-Kassem, 2017) found that non-performing loan has a significantly and negatively affect the ROAA of banks in Qatar; Likewise according to (Sinha \& Sharma, 2016) states that credit risk has a negatively impacts the bank profitability in Commercial Bank in India; And according to (Petria et al., 2015), found that credit risk has influence on bank profitability both on ROAA and ROAE in EU 27 banking systems; Likewise according to (Eduardus, Husnan, \& Hanafi, 2012) states that credit risk has insignificant impact on bank profit efficiency. (Erdogan \& Aksoy, 2016) found that the increase in non-performing loans among total loans, it was observed that profitability is inclined to decrease commercial banks' profits in Turkey. Although it is not in line with (Buchory, 2016) which state that NPL has a positive effect on profitability, the effect is not significant.

And the results of the t-test value between OEOI on Profit is -1.102 with a value of significant 0.287 was upper 0.05. This means that the OEOI has a positive effect on profit even though it is not significant. Therefore the third hypothesis: OEOI has a significant negative effect on Profit, accepted. The findings of this study support previous research by (Ramadan et al., 2011) stated that high Jordanian bank profitability tends to be associated with the efficiency of cost management. Likewise according to (Le Thanh et al., 2017) stated that management expense also has a negative relationship with the profitability of banks in the commercial banks listed on Vietnam's Stock Exchange. Then, according to (Islam \& Rana, 2017), operating expenses have a significant effect on the profitability of the selected private commercial banks in Bangladesh. And according to (El-Kassem, 2017) stated that cost to income ratio negatively and significantly impacts the performance of banks in Qatar measured by ROAA. Although it is not in line with (Sinha \& Sharma, 2016) which found that operating efficiency has been found to be significantly and positively affecting the bank profit. Furthermore, the results of study (Buchory, 2016) state that operating efficiency as measured by operating expense to operating income had a negative effect on profitability significantly.

Finally, from the results of the F-test was 4.893 with a value of significance 0.013 is below 0.05 . This means that the LDR, NPLs, and OEOI simultaneously significant effect on Profit. Therefore the fourth hypothesis: LDR, NPLs, and OEOI have a significant effect on Profit, accepted. Findings of this study support previous research by (Islam \& Rana, 2017); (Menicucci \& Paolucci, 2016); (Samad, 2015); (Buchory, 2016); (Egbe \& Collins, 2014); (Yigermal, 2017) which states that the LDR has an effect on profit. Then according to (Islam \& Rana, 2017); (El-Kassem, 2017); (Sinha \& Sharma, 2016); (Petria et al., 2015); (Eduardus et al., 2012), (Erdogan \& Aksoy, 2016); and (Buchory, 2016) which states that NPLs have an effect on profit. And according to (Ramadan et al., 2011); (Le Thanh et al., 2017); (Islam \& Rana, 2017); (ElKassem, 2017); (Sinha \& Sharma, 2016); and (Buchory, 2016) found that that operating efficiency as measured by operating expense to operating income had a negative effect on profitability significantly has an effect on profit.

\section{Conclusion}

Conclusion of this study is partially LDR has a positive effect although the effect is not significant on Profit; NPLs have a negative effect on Profit and the effect is significant; OEOI has a negative effect even though the effect is not significant on Profit; Simultaneously, the variable LDR, NPLs, OEOI have a significant effect on profit. In other words, the results of this study found that banking intermediation has an effect on profit growth although it is not significant. Although banking intermediation has decreased, the bank's profits have grown, meaning there is an anomaly between bank intermediation and profit growth. When banking intermediation is not optimal, the management of credit quality or credit risk can increase profits. Similarly, operating efficiency can increase profit growth even though it is not significant.

The results of this study prove that when the banking intermediary function is not running optimally, mainly due to the low growth of credit so that it will impact on profitability, the bank must increase the business of banks other than credit, for example investing in profitable securities, then increasing income 
from fee-based income such as from export-import transactions and other bank services. In addition, banks must manage their loan portfolios well so that good credit quality can be maintained. And finally the bank must achieve efficiency by reducing operational costs such as cost of funds that are expensive and reduce unnecessary costs.

\section{References}

Buchory, H. A. (2016). Determinants of banking profitability in Indonesian regional development bank. Actual problems of economy, (3), 308-318. http://www.irbis-nbuv.gov.ua/cgibin/irbis_nbuv/cgiirbis_64.exe?I21DBN=LINK\&P21DBN=UJRN\&Z21ID=\&S21REF=10\&S21CNR=20\&S21STN=1 $\&$ S21FMT $=$ ASP_meta\&C21

Eduardus, T., Husnan, S., \& Hanafi, M. M. (2012). Determinants of bank profit efficiency: Evidence from Indonesia. International Journal of Economics and Finance Studies, 4(2), 163-173. https://dergipark.org.tr/en/pub/ijefs/issue/26153/275449

Egbe, E., \& Collins, E. U. (2014). The Determinants of Bank Profit: A Disaggregated Analysis of Commercial Bank's Profit in Nigeria. International Journal of Business and Social Science, 5(5). https://ijbssnet.com/journals/Vol_5_No_5_1_April_2014/24.pdf

El-Kassem, R. C. (2017). Determinants of Banks' Profitability: Panel Data from Qatar.

ERDOGAN, M., \& AKSOY, E. E. (2016). Banking Regulation and Determinants of Banks' Profits: Empirical Evidence from Turkey. Eurasian Journal of Business and Economics, 9(17), 109-124. DOI: https://doi.org/10.17015/ejbe.2016.017.07

Financial Service Authority of Republic Indonesia Regulation No.18/POJK.13/2016 about Implementation of Risk Management for Commercial Banking. (2016).

Financial Service Authority of Republic Indonesia, Indonesia Banking Statistics. (2017). Retrieved from

Ghosh, A. (2012). Managing risks in commercial and retail banking: John Wiley \& Sons.

Gunawan, A., \& Wahyuni, S. F. (2014). Effect of financial ratios on profit growth in trading companies in Indonesia. Scientific Journal of Management and Business, 13 (1). https://doi.org/10.30596/jimb.v13i1.102

Harahap, S. S. (2015). Critical Analysis of Financial Statements (Twelfth Printing). Jakarta: PT. Raja Grafindo Persada. Indonesian Bank Regulation No. 11/25/PBI/2009 about Implementation of Risk Management for Commercial Banking. (2009).

Islam, M. A., \& Rana, R. H. (2017). Determinants of bank profitability for the selected private commercial banks in Bangladesh: A panel data analysis. Banks \& bank systems, (12 (3) (cont.), 179-192. https://www.ceeol.com/search/article-detail?id=746249

Koch, T., W. et.al. (2014). Bank Management: A Decision-Making Perspective, Cencage Learning sia Pte Ltd, Singapore.

Le Thanh, T. A. M., TRANG, P. X., \& Le Nhat, H. A. N. H. (2017). Determinants of Bank Profitability: The Case of Commercial Banks Listed on the Vietnam's Stock Exchange. Journal of Business, 1(2), 1-12. http://researchexcellence.com/journals/JBS-01122017.pdf

Menicucci, E., \& Paolucci, G. (2016). The determinants of bank profitability: empirical evidence from European banking sector. Journal of financial reporting and Accounting. https://www.emerald.com/insight/content/doi/10.1108/JFRA-05-2015-0060/full/html

Petria, N., Capraru, B., \& Ihnatov, I. (2015). Determinants of banks' profitability: evidence from EU 27 banking systems. Procedia economics and finance, 20(15), 518-524. https://www.researchgate.net/profile/Iulian_Ihnatov/publication/276859244_Determinants_of_Banks'_Profitability_Evi dence_from_EU_27_Banking_Systems/links/560b952e08ae840a08d6a57d/Determinants-of-Banks-Profitability-

Evidence-from-EU-27-Banking-Systems.pdf

Ramadan, I. Z., Kilani, Q. A., \& Kaddumi, T. A. (2011). Determinants of Bank Profitability: Evidence from Jordan. International Journal of Academic Research, https://www.researchgate.net/profile/Thair_Kaddumi/publication/286143663_Determinants_of_bank_profitability_Evid ence_from_Jordan/links/5a9d7651aca2721e3f33d7f3/Determinants-of-bank-profitability-Evidence-from-Jordan.pdf Rose, P. S., \& Hudgins, S. C. (2013). Bank Management \& Financial Services (9th Editio).

Samad, A. (2015). Determinants bank profitability: Empirical evidence from Bangladesh commercial banks. International journal of financial research, 6(3), 173-179. http://dx.doi.org/10.5430/ijfr.v6n3p173 
Sinha, P., \& Sharma, S. (2016). Determinants of bank profits and its persistence in Indian Banks: a study in a dynamic panel data framework. International Journal of System Assurance Engineering and Management, 7(1), 35-46. https://doi.org/10.1007/s13198-015-0388-9

Subramanyam, K. R. (2009). Financial statement analysis. Includes index. http://digilib.stiem.ac.id:8080/xmlui/handle/123456789/60

Sugiyono, P. D. (2013). Quantitative, Qualitative and R \& D Research Methods. Bandung: Alfabeta Cv.

Wibisono, S. A., \& Triyonowati, T. (2016). The effect of financial performance on earnings growth in automotive companies on the IDX. Journal of Management Science \& Research. Surabaya: Indonesian College of Economics (STIESIA), 5 (12), 2461-0593.

Yigermal, M. E. (2017). The Determinants of Private Commercial Banks Profitability: In the Case of Selected Ethiopian Private Banks. International Journal of Economic Behavior and Organization, 5(1), 25-35. 